\title{
Renal solute load in preterm infants
}

\author{
M De Curtis, J Senterre, J Rigo
}

\begin{abstract}
We performed metabolic balance studies in 77 preterm infants fed on human milk or adapted formulas, to determine the renal solute load and compared it with the potential renal solute load estimated by the composition of the diet or the urine according to Ziegler's, Bergman's, and Shaw's calculations. The renal solute load found in preterm infants was lower than that observed in young full term infants. Although all calculations predicted the renal solute load well, the equation proposed by Ziegler and Fomon from dietary protein and electrolyte load appears to be the simplest to calculate renal solute load accurately in preterm infants.
\end{abstract}

Renal solute load consists of the metabolic end products, especially nitrogenous compounds and electrolytes, that must be excreted by the kidneys. These solutes arise from endogenous sources and from the diet.

Prediction of renal solute load is important because renal function is not fully developed in the neonatal period, particularly in preterm infants. Indeed because of their limited renal concentrating ability, immature infants can develop negative water balance when fed on formulas with a high renal solute load, or if they are given a low water intake, or develop increased extrarenal losses of water.

Ziegler and Fomon derived a simple method to predict renal solute load from dietary protein and electrolyte intake in growing full term infants of 4000 to $7000 \mathrm{~g}$ fed cows' milk. ${ }^{1}$ Because some of the assumptions in their calculations are not appropriate for growing infants with immature renal function Bergman, Ziegler, and Fomon published another method for predicting the renal solute load in growing preterm infants. ${ }^{2}$

Shaw et al have described the estimation of renal solute load in growing preterm infants from urinary excretion of urea and electrolytes, assuming a retention of nitrogen, sodium, and potassium based on rates of intrauterine accretion. ${ }^{3}$

The aim of this study was to compare the potential renal solute load (calculated from the equations proposed by these authors) and the measured renal solute load in preterm infants fed on human milk or different formulas during metabolic balances.

Patients and methods

Metabolic balance studies were carried out in 77 male low birthweight infants of appropriate weight for gestational age; 16 were fed on human milk and 61 on adapted formulas. There were no significant differences between the two groups in mean (SD) birth weight (1788 (199) compared with $1786(204) \mathrm{g})$, gestational age (33 (2) compared with 33 (2) weeks), age, and weight at beginning of the study (21 (7) compared with 20 (7) days) and (2056 (230) compared with 2025 (277) g).

None of the infants had any congenital abnormality or medical problems at the time of the studies.

Informed consent was obtained from the parents.

NUTRITIONAL BALANCE

The infants were fed by nasogastric tube or by bottle when possible. The approximate volume of human milk or formula needed for the entire study was pooled, carefully mixed, and an aliquot was taken for chemical analysis.

The nutritional balance consisted of precise measurements of intake and output over a three day period, during which the infant lay on a metabolic bed placed within an incubator as previously described. ${ }^{4}$ The intake of feed was measured volumetrically. Stool and urine were collected separately.

During each three day period urine was collected into a bottle containing $2 \mathrm{ml} 10 \%$ thymol solution in isopropanol and kept cold in ice water. At the end of each 24 hours, urine collection was stored at $-20^{\circ} \mathrm{C}$. After thawing analyses were performed on the three day pooled urine collection.

ANALYSIS

From aliquots of prepared milk and urine, nitrogen was determined by the standard microKjeldhal method, sodium and potassium were measured by a flame photometer, and chloride by mercuric titration.

Energy content of human milk was estimated at $0.28 \mathrm{MJ} / 100 \mathrm{ml}$ while that of infant formulas was as stated by the manufacturers and the range varied between 0.26 and $0.33 \mathrm{MJ} / 100 \mathrm{ml}$.

Urine osmolality was determined by the Fiske apparatus, creatinine was determined using a modification of Jaffe's method, ammonia by the Berthelot reaction, and uric acid, calcium, and phosphorus by methods used for their measurement in milk.

CALCULATION OF POTENTIAL RENAL SOLUTE LOAD

The true renal solute load was calculated from
80131 Naples, Italy.

Accepted 16 August 1989 
urinary volume and urinary osmolality. Potential renal solute load, calculated as proposed by Ziegler and Fomon, was defined as the sum of nitrogen, sodium, potassium, and chloride in the intake. Each gram of dietary protein was considered to yield $4 \mathrm{mmol}$ of renal solute load.

According to the equation proposed by Bergman et al, the potential renal solute load was also evaluated from the sum of dietary nitrogen, sodium, potassium, chloride, and phosphate. These workers assumed that all dietary protein is metabolised and all the metabolic products are presented to the kidney for excretion, so each gram of dietary protein was considered to yield $5.7 \mathrm{mmol}$ of renal solute load.

Because the growing infant incorporates into new tissue a portion of those substances present in the diet (protein, potassium, phosphate, etc), which in the non-growing subject would be presented to the kidney for excretion, an 'osmolar equivalent of weight gain' was removed from the calculated potential renal solute load. A theoretical estimate of the size of this sparing effect, based on the body composition of the newborn infant, suggests an osmolar equivalent of weight gain of $0.9 \mathrm{mmol} / \mathrm{g}$ weight gain. ${ }^{2}$

Finally, the potential renal solute load was evaluated using Shaw's calculations, from the equation: total urine solute $=$ (urine urea $/ \mathrm{mmol} /$ day) $\times 2$ (urinary $\mathrm{Na}+$ urinary $\mathrm{K} / \mathrm{mmol} /$ day). ${ }^{3}$ Urine urea and urine sodium $(\mathrm{Na})$ and potassium $(\mathrm{K})$ were calculated by subtracting from the intake a quantity assumed to be retained in growing preterm infants: $320 \mathrm{mg}$ nitrogen $/ \mathrm{kg} /$ day, $1 \mathrm{mmol} / \mathrm{kg} /$ day of sodium, and $0.7 \mathrm{mmol} /$ $\mathrm{kg} /$ day of potassium. ${ }^{3}$ day.

All values are expressed per kg body weight/

\section{STATISTICAL ANALYSIS}

The significance of the difference between the arithmetic means was evaluated using Student's $t$ test. The association between potential renal solute load and measured renal solute load was analysed using the method of least squares and linear regression analysis.

\section{Results}

The table reports the results of metabolic balance studies in the two groups expressed as mean (SD)/kg body weight/day. Volume and energy intake were similar in the two groups.

Nitrogen intake in the formula fed group was significantly higher than in the group fed human milk because of the higher protein content of formula. The infants fed on human milk received an average of $424 \mathrm{mg}$ nitrogen $/ \mathrm{kg} /$ day corresponding to a net protein intake of $2 \cdot 7$ $\mathrm{g} / \mathrm{kg} /$ day. Infants fed on formula received an average of $548 \mathrm{mg}$ nitrogen $/ \mathrm{kg} /$ day corresponding to a net protein intake of $3.4 \mathrm{~g} / \mathrm{kg}$.

Phosphorus intake was higher in formula fed infants than in the group fed on human milk. Urinary volume was similar in the two groups and represented about three quarters of the volume intake. Nitrogen excretion was significantly higher in formula fed infants and averaged $21 \%$ of the nitrogen intake in the group fed
Results of metabolic balance studies in the two groups. Values are expressed as mean (SD)/kg body weight/day unless otherwise stated

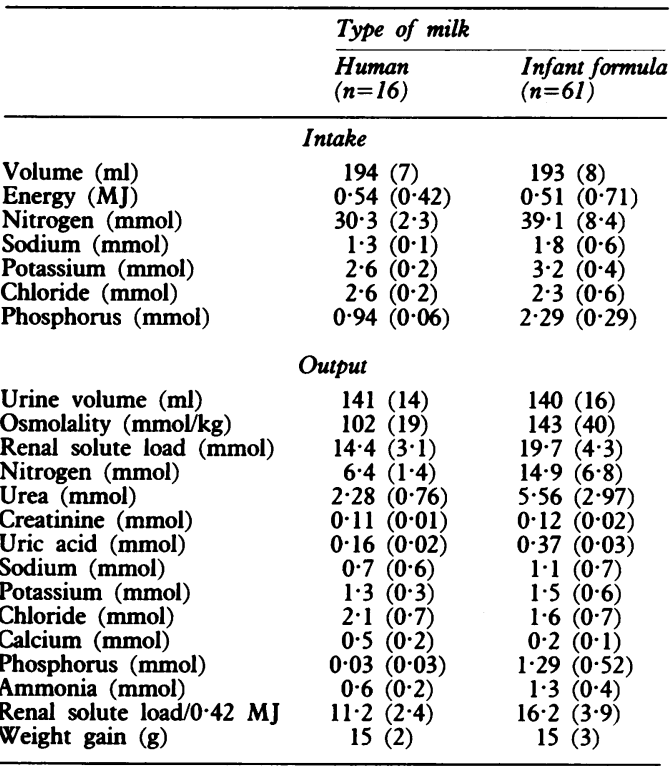

on human milk and $38 \%$ in the formula fed group. Distribution of total urinary nitrogen was $72 \%$ in urea, $10 \%$ in uric acid, $9 \%$ in ammonia, $5 \%$ in creatinine, and $2 \%$ undetermined in the group fed human milk and $76 \%$, $10 \%, 9 \%, 4 \%$, and $1 \%$ respectively in the formula fed group.

As shown in fig 1 , the contribution of urea to the renal solute load increased with increasing renal solute load.

Combined urinary excretions of sodium, chloride, and potassium accounted for approximately $60 \%$ of dietary intake in both groups (on average $63 \%$ in the group fed human milk and $57 \%$ in the formula fed group). The remainder of the renal solute load was almost constant.

There was a highly significant association $(\mathrm{r}=0.74 ; \mathrm{p}<0.001)$ between potential renal solute load estimated by Ziegler and Fomon and

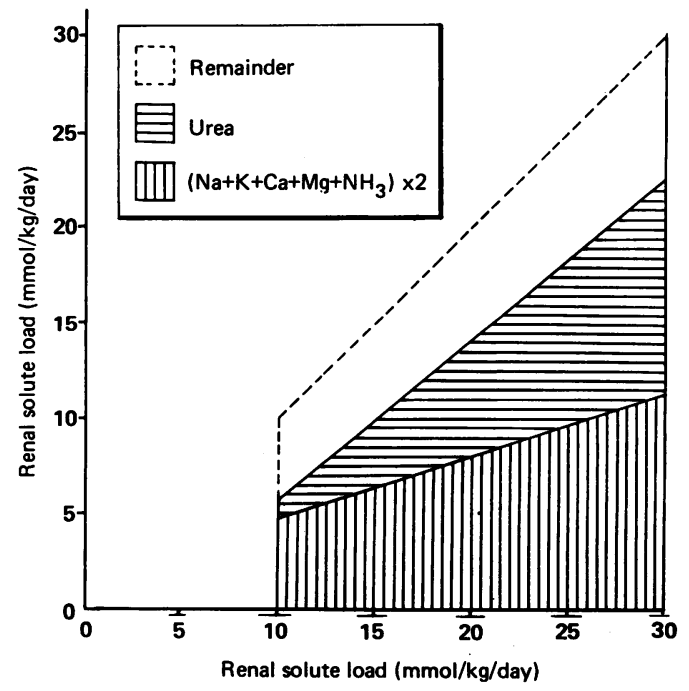

Figure 1 Composition of renal solute load. $\mathrm{Na}$, sodium $\mathrm{K}$, potassium; $\mathrm{Ca}$, calcium; $\mathrm{Mg}$, magnesium; and $\mathrm{NH}_{3}$, ammonia. 


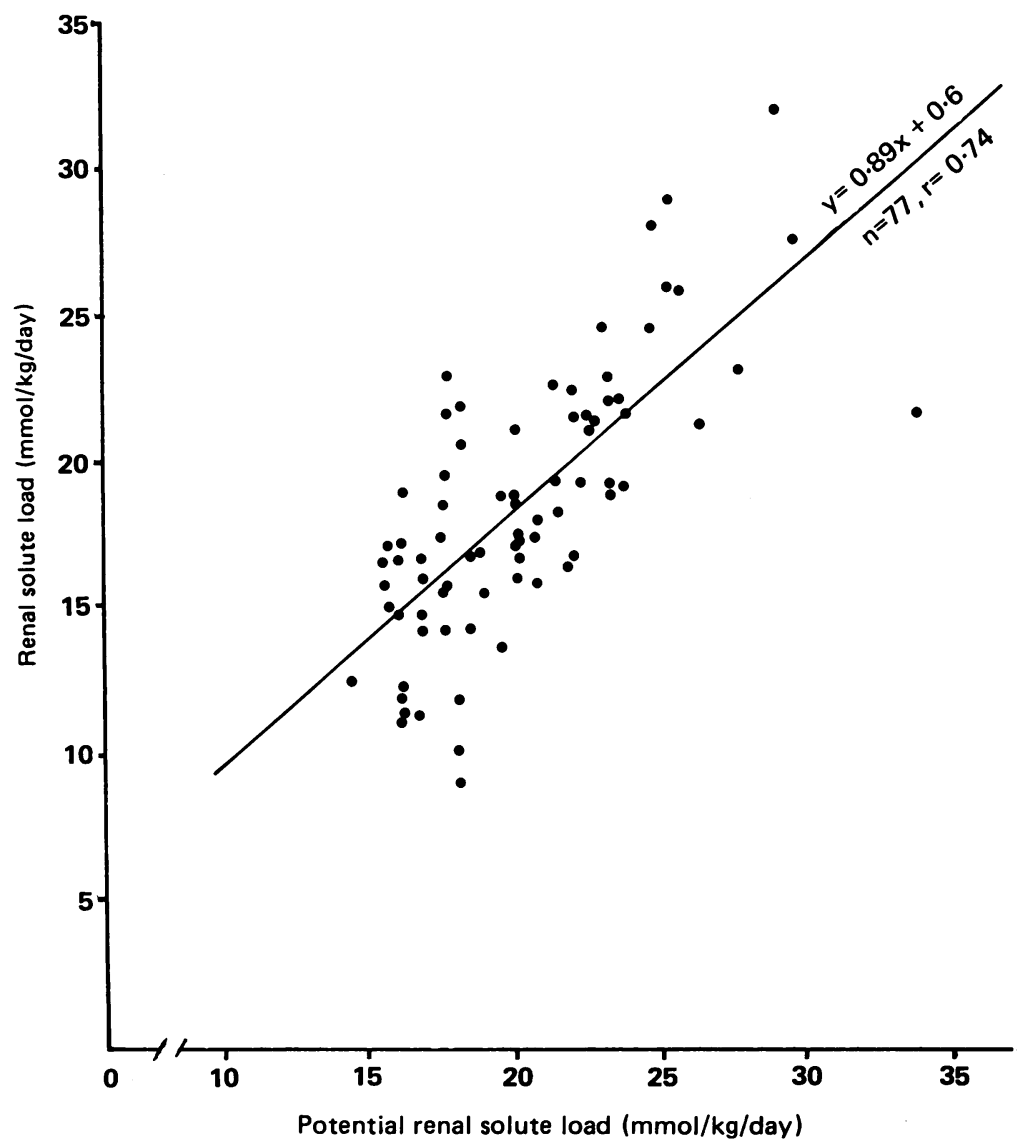

Figure 2 Relationship between the potential renal solute load estimated by Ziegler and Fomon' and true renal solute load found.

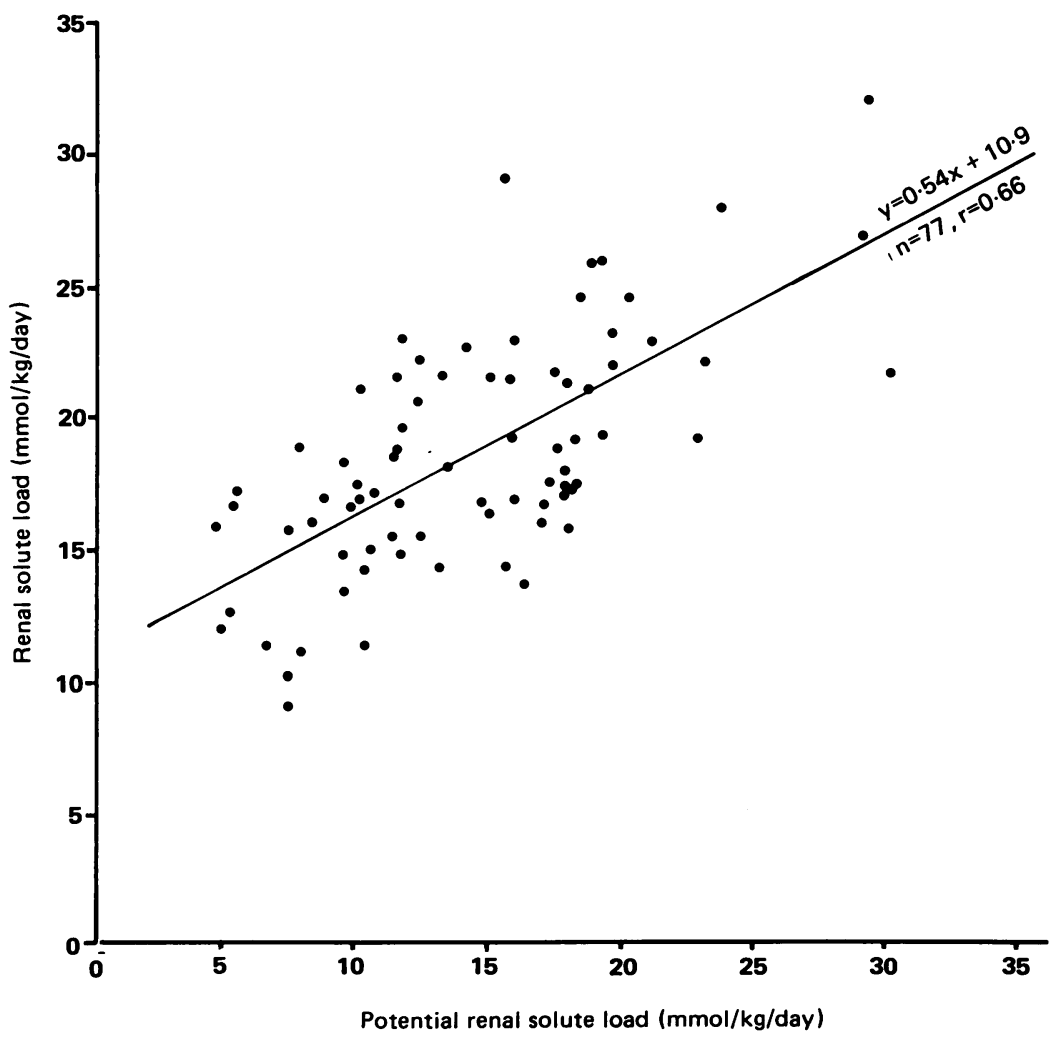

Figure 3 Relationship between the potential renal solute load estimated by Bergman et al ${ }^{2}$ and true renal solute load found. the measured renal solute load (renal solute load $=0.89$ potential renal solute load +0.6 ) (fig 2). There was also a significant relationship between the measured renal solute load and the potential renal solute load as estimated according to Bergman et al $(\mathrm{r}=0.66 ; \mathrm{p}<0.001)$ (renal solute load $=0.54$ potential renal solute load + 10.9) (fig 3); and as estimated according to Shaw $(r=0.74 ; p<0.001)$ (renal solute load $=0.6$ potential renal solute load +10.5$)$.

\section{Discussion}

Solute that must be excreted in the urine is referred to as the renal solute load and its main contributors are nitrogenous substances and electrolytes. The measured renal solute load in our infants ranged from 9 to $18.9 \mathrm{mmol} / \mathrm{kg}$ body weight/day in the group fed human milk and from 11.3 to 32.3 in the formula fed group. The renal solute load expressed/0.42 MJ energy intake was on average 11.2 and $16.2 \mathrm{mmol} / \mathrm{kg}$ body weight/day in both groups. These results appear lower than those observed in young infants. ${ }^{6}$ This can be explained by the higher growth rate of preterm infants associated with a raised nitrogen and mineral retention rate. Mean urinary osmolar concentration was on average about $102 \mathrm{mmol} / \mathrm{l}$ (range 69-129) in the group fed human milk and $143 \mathrm{mmol} / \mathrm{l}$ (range 92-212) in the formula fed group. An estimate of renal solute load should be simple if it is to be useful in paediatric practice. The simplest calculation to predict renal solute load in preterm infants is that of Ziegler and Fomon because it is based on dietary intake of nitrogen and three major minerals: sodium, potassium, and chloride.

It is quite clear that the equation of Ziegler and Fomon (fig 2) not only produces results with a good correlation coefficient, but a slope that is fairly close to the line of equality. Thus across the range tested the equation is equally effective at predicting the true solute load. By contrast the data produced by using Shaw's equation (fig 4) give a similar correlation coefficient but a slope that is very different from zero and a fairly large constant value. This means that the formula is very inaccurate when used at the lower end of the scale: for example when the equation predicts a value of about $7 \mathrm{mmol} / \mathrm{kg} /$ day, the true value is likely to be about 14 . The same criticism applies to Bergman's equation (fig 3 ) in which the slope is even shallower and the constant value slightly higher.

Bergman's calculation, which also considers the phosphorus intake, and the weight gain, and assumes that all dietary protein is excreted as urea, gave a less good estimation of the true renal solute load.

The ranges of urinary osmolality in our study appear particularly low. This could be due to high urinary volume and to low extrarenal water losses. Assuming that $10 \mathrm{ml} / \mathrm{kg} /$ day of water are retained for a normal growth of $15 \mathrm{~g} / \mathrm{kg} / \mathrm{day}$ by a preterm infant, ${ }^{78}$ we estimated the extrarenal water lost at $43 \mathrm{ml} / \mathrm{kg} /$ day in both groups studied. This is represented in part by water lost in faeces, which is almost constant (5-10 $\mathrm{ml} / \mathrm{kg} / \mathrm{day}$ ) and by insensible water losses that 


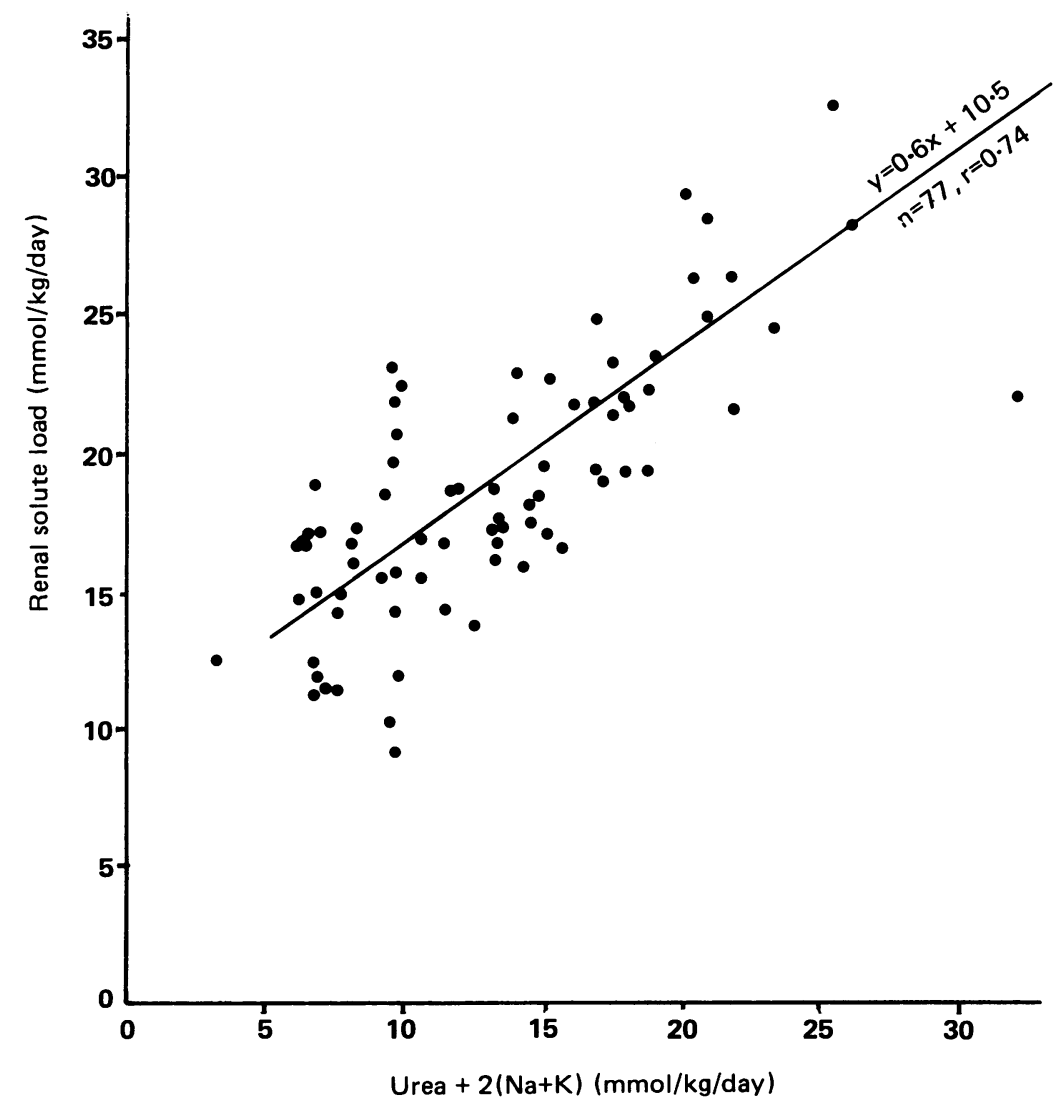

Figure 4 Relationship between the potential renal solute load estimated by Shaw et al ${ }^{3}$ and true renal solute load found. are variable and increase with decreasing body weight and gestational age.

The main conclusion of this study is that in healthy preterm infants fed on human milk and adapted formulas there is a relatively low renal solute load in comparison with older infants. This will not stress the urinary concentration mechanism if the extrarenal water losses are low and the urinary volume high.

The calculation proposed by Ziegler and Fomon to predict renal solute load in term infants appears to be a simple and a precise method for estimating renal solute load in healthy preterm infants.

1 Ziegler EE, Fomon SJ. Fluid intake, renal solute load and water balance in infancy. $\mathcal{F}$ Pediatr 1971;78:561-8.

2 Bergman KE, Ziegler EE, Fomon SJ. Water and renal solute load. In: Fomon SJ, ed. Infant nutrition. 2nd Ed. Toronto: WB Saunders, 1974:262.

3 Shaw JCL, Jones A, Gunther M. Mineral content of brands of milk for infant feeding. Br Med J 1973;ii:12-5.

4 Senterre J. Nitrogen balances and protein requirement of preterm infants. In: Visser HKA, ed. Nutrition and metabolism of the fetus and infant. The Hague: Martinus Nijhoff, 1979 195-212.

5 Senterre J, Sodoyez-Goffaux F, Lambrechts A. Metabolic balance studies in premature babies. I. Methodology. Acta Paediatrica Belgica 1971:25:133-42.

6 Senterre J, Lambrechts A Nitrogen, fat and minerals' balances in premature infants fed acidified or nonacidified balances in premature infants fed acidified or nonacidified

7 Reichman B, Chessex P, Velleren G, et al. Dietary composition and macronutrient storage in preterm infants. Pediat-
, et al rics 1983;72:322-8.

8 Putet G, Senterre J, Rigo J, Salle B. Nutrient balance, energy utilization and composition of weight gain in wery low birth weight infants fed pooled human milk or a preterm formula. $\mathcal{f}$ Pediatr 1984;105:79-85.

9 Ziegler EE, O'Donnell A, Nelson SE, Fomon SJ. Body composition of the reference fetus. Growth 1976;40:329-41. 